\title{
Analysis of the main socio-economic impacts of wind energy in Europe
}

\author{
Margarita Ortega $^{1}$, Pablo del Río ${ }^{2}$, Carlos Gamarra ${ }^{1}$ and Eduardo Montero ${ }^{1}$ \\ ${ }^{1}$ Department of Electromechanical Engineering \\ University of Burgos. EPS Burgos. \\ Avd. Cantabria, s/n 09006 Burgos (Spain).e-mail: moizquierdo@ubu.es; cgamarra@ubu.es; emontero@ubu.es \\ ${ }^{2}$ Institute for Public Policies and Goods. National Research Council of Spain (CSIC) \\ C/ Albasanz 26-28, 28037 Madrid (Spain).e-mail: pablo.delrio@csic.es
}

\begin{abstract}
.
The large increase in renewable energy sources (RES-E) penetration in the European Union (EU) has raised the concern of policy makers about the costs of public promotion of RES-E, in spite of the commitment of the European Commission to the deployment of RES-E in the last years.

This paper is focused on wind energy, because it is the renewable technology with the highest contribution to electricity mix in Europe (excluding hydro).

An economic analysis of wind energy contribution should not only take into account the policy costs of the deployment, which are finally paid by electricity consumers, but also its benefits, particularly those related to climate change mitigation and the reduction of fossil fuel dependence distributed among citizens.

The aim of this paper is to fill this gap and evaluate the policy costs and the most relevant benefits of wind energy deployment in the EU28 (28 Member States) using 2013 data. For this purpose, an innovated methodology internationally validated has been used.
\end{abstract}

The results show that the benefits considered are relevant and should be taken into account when support costs are assessed and in the future development of energy policies in Europe.

\section{Key words}

Renewable energy electricity, European support schemes, $\mathrm{CO}_{2}$ abatement, fossil fuel savings, import savings.

\section{Introduction}

Electricity generation, especially from fossil fuels, creates environmental and socio-economic impacts on third parties, which are not included in its price. These impacts are called externalities. Public support to RES-E internalizes the externalities in the prices and allows RES-E to penetrate the electricity market [1].

The penetration of RES-E in the EU has raised the concern about the costs of their public promotion. While it is true that RES-E support costs have increased significantly in the last decade and that it is certainly desirable to deploy RES-E at the lowest possible support costs, an analysis of the social contribution of RES-E should put those costs into perspective and also take into account the benefits of RES-E deployment. Notwithstanding their relevance, a quantification of the costs and benefits for different technologies and EU Member States (MS) has been absent in the literature, as noted by [2]. Three notable exceptions are [3], [4] and [5]. [3] compares the benefits associated to the $\mathrm{CO}_{2}$ emissions avoided with the costs of the Spanish FIT system and [4] analyses the avoided costs of imported fuels in Europe. [5] compares the policy costs of RES$\mathrm{E}$ deployment with the social benefits in terms of $\mathrm{CO}_{2}$ emissions reduction and fossil fuel savings in Germany, leading to the conclusion that the former outweigh the later.

The aim of this paper is to close this gap and quantify, in monetary terms, the policy costs and some of the most relevant benefits of wind energy deployment in the EU MS, including climate change mitigation and fossil fuel savings in 2013. The analysed impacts (costs and benefits) of wind energy deployment fall on different actors, as stated by [2], who classifies the impacts in system related, distributional and macroeconomic effects. In strictly economic terms, benefits and costs cannot be compared between each, because the respective impacts fall on different types of actors. Therefore, a costbenefit analysis is not carried out.

The paper is structured as follows. Section 2 provides a brief background on wind energy generation and support policies in the EU. Section 3 provides the methodology to calculate the benefits and costs of wind energy. The results are provided and discussed in section 4. Finally, section 5 concludes.

\section{Current situation in Europe}

In 2013, the base year for this analysis, net electricity production in the EU amounted to 3,097 TWh [6] and was concentrated in a few countries. Germany, France, United Kingdom, Spain and Italy accounted for $65 \%$ of electricity generation.

The EU has a diversified electricity generation mix. Several energy sources have significant shares in this mix in 2013, including coal $(27.3 \%)$, nuclear $(26.8 \%)$, natural gas $(15.3 \%)$ and renewable energy sources $(28.0 \%)$. Oil has a negligible share in electricity generation $(2.5 \%)$, although it is the dominant fuel in Malta and Cyprus. Within RES, wind (7.5\%), 
has developed considerably in the last years, although hydro $(12.8 \%)$ still dominates. Biomass, biogas and waste $(4.8 \%)$, solar $(2.7 \%)$ and geothermal $(0.2 \%)$ are growing fast but have smaller shares [18].

Wind energy has multiplied by five its contribution to electricity mix in the last decade. It is one the technologies, together with photovoltaics (PV), with the fastest development in all MS. This is the reason why this paper is focus on it.

Due to the higher investment costs of RES-E, support schemes have been enacted in all the MS and they have a crucial role on RES-E deployment. The analysis of the performance of RES-E support schemes in the EU has been the focus of much research in the last decade, for example [7] and [8].

Basically, support schemes can be split into three types [9]: - Price-base mechanisms. Two options are available: feed-in tariffs (FITs), which guarantee a fixed price per $\mathrm{kWh}$ electricity and feed-in premiums (FIPs), which are paid on top of the market price for electricity.

- Quantity-base mechanisms. Tradable green certificates (TGC) or renewable quota obligations (QO) require that a percentage of electricity generation come from RES-E. Tendering schemes (TN) are bidding systems in which developers compete for supply contracts to build RES-E capacity.

- Other instruments include tax exemptions (TE), investment incentives (II) and financial incentives (FI).

Table I. Instruments for wind energy deployment in the EU (2013). [10],[11] and [12]

\begin{tabular}{|c|c|c|}
\hline $\begin{array}{c}\text { MS - } \\
\text { Support mechanism }\end{array}$ & Main & Secondary \\
\hline Austria (AT) & FIT & \\
\hline Belgium (BE) & TGC & TE; II ${ }^{(11)}$ \\
\hline Bulgaria (BG) & FIT & $\mathrm{FI}^{(12)}$ \\
\hline Cyprus (CY) & FIT & II \\
\hline Czech Republic (CZ) & FIT/FIP ${ }^{(1)}$ & II, FI \\
\hline Germany (DE) & FIT/FIP & FI \\
\hline Denmark (DK) & $\mathrm{FIP}^{(2)} ; \mathrm{TN}^{(3)}$ & $\mathrm{II}^{(12)} ; \mathrm{FI}$ \\
\hline Estonia (EE) & FIP & II; TE \\
\hline Greece (EL) & FIT & II; TE \\
\hline Spain (ES) & FIT/FIP ${ }^{(4)}$ & $\mathrm{TE}$ \\
\hline Finland (FI) & FIP & II \\
\hline France (FR) & $\mathrm{FIT}^{(2)} ; \mathrm{TN}^{(3)}$ & II \\
\hline Croatia (HR) & FIT & FI \\
\hline Hungary (HU) & FIT & II \\
\hline Ireland (IE) & FIT & $\mathrm{TE}$ \\
\hline Italy (IT) & FIT $^{(5)} ;$ FIP $^{(6)} ;$ TGC$;$ TN $^{(7)}$ & $\mathrm{TE}$ \\
\hline Lithuania (LT) & FIT $^{(8)} ;$ FIT/TN ${ }^{(9)}$ & II, FI \\
\hline Luxembourg (LU) & FIT & II \\
\hline Latvia (LV) & FIT & II; TE \\
\hline Malta (MT) & & $\mathrm{II}^{(13)} ; \mathrm{FI}$ \\
\hline The Netherlands (NL) & FIP & $\mathrm{FI}^{(2)}$ \\
\hline Poland (PL) & TGC & FI; II; TE \\
\hline Portugal (PT) & FIT; TN & TE \\
\hline Romania (RO) & TGC & II \\
\hline Sweden (SE) & TGC & TE; II $^{(3)}$ \\
\hline Slovenia (SI) & FIT; FIP & II; FI \\
\hline Slovakia (SK) & FIP & II, TE \\
\hline United Kingdom (UK) & TGC; FIT $^{(10)}$ & TE \\
\hline
\end{tabular}

${ }^{(1)}$ : P<20MW; ${ }^{(2)}$ : On-shore $;{ }^{(3)}$ : Off-shore; ${ }^{(4)}$ : Existing plants before January, 2012; ${ }^{(5)}$ : Existing plants $\mathrm{P}<1 \mathrm{MW} ;{ }^{(6)}$ : Existing plants $\mathrm{P}>1 \mathrm{MW}$ and $\mathrm{P}<1 \mathrm{MW}$ which did not chose FIT before; (7): New plants - Large projects; ${ }^{(8)}: \mathrm{P}<10 \mathrm{~kW} ;{ }^{(9)}: \mathrm{P}>10 \mathrm{~kW} ;{ }^{(10)}$; $\mathrm{P}<5 \mathrm{MW} ;{ }^{(11)}$ : Only in Brussels; ${ }^{(12)}$ : Small scale plants; ${ }^{(13):} \mathrm{P}<3.7 \mathrm{~kW}$
As it is shown in Table I, FITs were the main support used in the EU in 2013 for wind energy, followed by FIPs and TGC. Tenders have been much less common, although they are used in a few MS for specific projects and technologies (e.g., wind off-shore in Denmark). These instruments are sometimes combined with other, including investment subsidies (II), soft loans (FI), tax exemptions (TE) or net metering (NM) which are complementary to the aforementioned ones [11].

Recently, the European Commission has stressed the need to have cost-effective and market-based instruments, suggesting that feed-in tariffs (FITs) have been too expensive and not suitable to integrate an increasing volume of RES-E in electricity markets [13].

\section{Methodology}

The deployment of RES-E brings two main benefits: $\mathrm{CO}_{2}$ emissions reductions and lower fossil-fuel consumption levels. These benefits are quantified in monetary terms in this paper. Other benefits have been reported in the literature, like other environmental benefits (reductions of local pollutants such as $\mathrm{SO}_{2}$ ), the merit-order effect, which refers to the reduction of the pool electricity price due to a greater penetration of RES-E, and job creation. They have not been considered in this paper, mostly due to de lack of reliable EU-wide data. Regarding the cost side, only policy support costs have been taken into account and not system generation costs, which would be needed for a cost-benefit analysis. The costs for the electricity system related to the variable character and the limited predictability of the generation of electricity from intermittent RES-E (usually called cycling costs and balancing costs) have not been included because their values compared to other impacts are negligible with low RES-E penetration levels, as argue [5] and [14]

In order to quantify in monetary terms the two considered benefits associated to wind energy deployment, a methodology proposed by the United Nations Framework Convention on Climate Change (UNFCCC) [15] has been used. This methodology was not originally conceived for this purpose and it is commonly used in the calculation of baselines in clean development mechanism (CDM) projects. [16] adapted the methodology and applied it to the Spanish case.

According to this methodology, $\mathrm{CO}_{2}$ emission factor can be obtained using three different alternatives:

1) Operating margin factor $(O M)$. It considers the existing power plants whose current electricity generation would be affected by the proposed RES-E project (i.e., by the RES-E project). The so-called Average OM alternative will be used in order to calculate the operating margin in this paper. The Average $\mathrm{OM}$ emission factor is calculated as the generationweighted average $\mathrm{CO}_{2}$ emissions per unit of net electricity generation of all generating power plants serving the system, including low-cost/must-run power plants 1 .

According to [15], electricity imports from other countries have been treated as an additional electricity generation technology. The calculation of the Average OM emission factor is based on the following equation:

$$
\mathrm{EF}_{\text {Average OM,y }}=\Sigma_{\mathrm{m}} \mathrm{EG}_{\mathrm{m}, \mathrm{y}} \cdot \mathrm{EF}_{\mathrm{EL}, \mathrm{m}, \mathrm{y}} \mathrm{g} / \Sigma \mathrm{EG}_{\mathrm{m}, \mathrm{y}}
$$

Where $\mathrm{EF}_{\text {Average OM.y }}$ is the operative margin factor in the year $y$ $\left(\mathrm{tCO}_{2} / \mathrm{MWh}\right) ; \mathrm{EG}_{\mathrm{m}, \mathrm{y}}$ is the net electricity generated by the

\footnotetext{
${ }^{1}$ Low-cost/must-run resources are power plants with low marginal generation costs or dispatched independently of the daily or seasonal grid load. Both nuclear and renewable energies (including hydro) belong to this category.
} 
technology $m$ in the year $y(\mathrm{MWh}), \mathrm{EF}_{\mathrm{ELm}, \mathrm{y}}$ is the $\mathrm{CO}_{2}$ emission factor of technology $m$ in the year $y ; m$ are the technologies serving the system (according to the Average OM definition, these are all the power generation technologies in the system) and $y$ is the year of reference.

2) Build margin factor (BM). It refers to prospective power plants whose construction would have been affected (delayed or cancelled) by the increase in RES-E generation. Since data on the installed capacity per fuel type are not available at European level and intermediate scenario has been considered, whereby a $50 \%$ substitution of coal and natural gas is assumed. As coal and natural gas thermal plants are not located in neither Cyprus nor Malta, a single scenario in which RES-E replaces fuel-oil is considered for these two countries. The BM emission factor will be the emission factor of the replaced technology or technologies.

3) Combined margin factor (CM). This is a weighted average of the two preceding factors. In this paper, the weighted average $\mathrm{CM}$ has been used, where the $\mathrm{OM}$ and the $\mathrm{BM}$ factors have equal weights. Three different scenarios have been assumed, corresponding to the scenarios chosen in the calculation of the BM factor:

$$
\mathrm{EF}_{\mathrm{CM}, \mathrm{y}}=0,5 \cdot \mathrm{EF}_{\text {Average OM, } \mathrm{y}}+0,5 \cdot \mathrm{EF}_{\mathrm{BM}, \mathrm{y}} \quad \text { [Eq. 2] }
$$

Where $\mathrm{EF}_{\mathrm{CM}, \mathrm{y}}$ is the combined margin factor in the year $y$, $\mathrm{EF}_{\text {Average } \mathrm{OM}, \mathrm{y}}$ is the operating margin factor (using the average

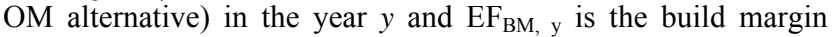
factor in the year $y$.

Therefore, this analysis takes into account the impacts of wind energy plants on the existing power plants $(\mathrm{OM})$ and the avoided construction of new facilities (BM).

\section{A. Benefits from $\mathrm{CO}_{2}$ emissions avoided}

The original UNFCCC methodology will be applied to calculate $\mathrm{CO}_{2}$ emission reduction related to wind deployment. [17] provides the emissions from fossil fuel combustion and the oxidation factors considered are those recommended by [18]. The oxidation factors for the three fuels considered are the following: coal $(99 \%)$, fuel-oil $(99.5 \%)$ and natural gas $(99.5 \%)$. The emissions factors are: coal $\left(97.3 \mathrm{tCO}_{2} / \mathrm{TJ}\right)$, fuel-oil $\left(77 \mathrm{tCO}_{2} / \mathrm{TJ}\right)$ and natural gas $\left(55.8 \mathrm{tCO}_{2} / \mathrm{TJ}\right)$.

In order to translate $\mathrm{CO}_{2}$ emissions reductions into monetary terms, the concept of the Social Cost of Carbon (SCC) has been used. The SCC is used to reflect the external costs of greenhouse gases emissions. It measures the full global cost today of an incremental unit of carbon emitted now, summing the full global cost of the damage it imposes over the whole of its time in the atmosphere. It measures the scale of the externality which needs to be incorporated into decisions on policy and investment options in government [19]. According to the review made by [20], values on the SCC show significant variations depending on the study being considered. The median of the values of the SCC in [20] has been used $\left(32 € / \mathrm{tCO}_{2}\right)$. This value is higher than the price of $\mathrm{CO}_{2}$ allowances under the EU Emission Trade System (EU ETS) in the reference year being considered $\left(4.5 € / \mathrm{tCO}_{2}\right.$ in 2013). However, it could be regarded as a reasonable scenario for the SCC, being the central value of the range analysed by [20]. Obviously, the monetary calculation of the avoided emissions would vary if the mode $\left(14 € / \mathrm{tCO}_{2}\right)$ or the average $\left(49 € / \mathrm{tCO}_{2}\right)$ were applied.

\section{B. Benefits from fossil fuels savings}

In order to calculate the fossil fuel savings as a result of wind energy deployment, final energy has been transformed into primary energy and the result has been multiplied by the price of energy. To calculate the conversion from final to primary energy and the price of energy, the original UNFCCC methodology is adapted, replacing the emission factors of participant technologies by the efficiency values and prices of these technologies, respectively.

The efficiency values considered for the transformation of primary energy into final energy have been obtained from [21]. It has been assumed that coal and fuel-oil plants were built before 2001 and that natural gas and biomass plants were built in 2006. For reasons of simplicity, it has been assumed that the efficiency of fossil fuel plants does not change when they are substituted by RES-E. In reality, however, a very small increase in those efficiencies could be expected [14].

The following equation is used to transform final energy into primary energy for both the $\mathrm{OM}$ and $\mathrm{BM}$ alternatives:

$1 \mathrm{MWh}$ (Primary energy) $=1 / \eta \mathrm{MWh}$ (Final energy) [Eq. 3]

To calculate the conversion factors of final energy into primary energy in the $\mathrm{CM}$ alternative, the emission factors in the $\mathrm{OM}$ and BM alternatives are replaced by the efficiency values of the considered fuels.

The prices of fossil fuels used in electricity generation have been obtained from [22]. Electricity imports have been treated as if they were an independent technology generator and data on the wholesale electricity prices from each MS for 2013 are provided by [10] or accessing the web-sites of official organisms in each MS. For those countries without available data and non-EU MS the average of the electricity price when available (45.1€/MWh in 2013) has been used. The following standard conversion factors have been applied: Coal: $1 \mathrm{MWh}=$ $0.21 \mathrm{t}$; Oil: $1 \mathrm{MWh}=0.61$ barrels; Natural gas: $1 \mathrm{MWh}=3.44$. 106 Btu. [60]

According to data provided by the International Monetary Fund [23], the price of uranium in 2013 was $38.5 € /$ pound. Assuming the unitary fuel consumption in [24], the price of fuel for nuclear electricity generation was $0.44 € / \mathrm{MWh}$. This price is negligible compared to the price of other fossil fuels and, thus, it was not included in the study.

Finally, it has been assumed that biomass, biogas and wastes are indigenous energy sources and, thus, that there are not any imports.

Table II shows the conversion factor from final to primary energy, the $\mathrm{CO}_{2}$ emission factor $\left(\mathrm{tCO}_{2} / \mathrm{GWh}_{\text {final }}\right)$ and the price $\left(€ / \mathrm{MWh}_{\text {primary }}\right)$ that is obtained when applying this methodology. 
Table II. Combined margin factors used: conversion factor (final energy to primary energy), emission factors and prices. Year 2013

\begin{tabular}{|c|c|c|c|}
\hline $\mathrm{MS}$ & $\mathrm{MWh}_{\text {final }} / \mathrm{MWh}_{\text {primary }}$ & $\mathrm{tCO}_{2} / \mathrm{MWh}_{\text {final }}$ & $€ / \mathrm{MWh}_{\text {primary }}$ \\
\hline $\mathrm{AT}$ & 1,72 & 0,35 & 17,2 \\
\hline $\mathrm{BE}$ & 2,19 & 0,37 & 15,3 \\
\hline $\mathrm{BG}$ & 2,19 & 0,48 & 14,2 \\
\hline $\mathrm{CY}$ & 2,30 & 0,62 & 49,0 \\
\hline $\mathrm{CZ}$ & 2,25 & 0,50 & 14,2 \\
\hline $\mathrm{DE}$ & 2,13 & 0,51 & 15,9 \\
\hline $\mathrm{DK}$ & 1,93 & 0,45 & 17,6 \\
\hline $\mathrm{EE}$ & 2,14 & 0,61 & 17,7 \\
\hline $\mathrm{EL}$ & 2,00 & 0,54 & 19,9 \\
\hline $\mathrm{ES}$ & 2,04 & 0,42 & 15,9 \\
\hline $\mathrm{FI}$ & 2,13 & 0,39 & 14,4 \\
\hline $\mathrm{FR}$ & 2,37 & 0,33 & 11,1 \\
\hline $\mathrm{HR}$ & 1,69 & 0,36 & 22,1 \\
\hline $\mathrm{HU}$ & 2,09 & 0,38 & 16,5 \\
\hline $\mathrm{IE}$ & 1,97 & 0,50 & 20,6 \\
\hline $\mathrm{IT}$ & 1,91 & 0,45 & 20,5 \\
\hline $\mathrm{LT}$ & 1,90 & 0,41 & 27,2 \\
\hline $\mathrm{LU}$ & 1,61 & 0,33 & 25,9 \\
\hline $\mathrm{LV}$ & 1,71 & 0,35 & 22,8 \\
\hline $\mathrm{MT}$ & 2,33 & 0,64 & 49,8 \\
\hline $\mathrm{NL}$ & 1,98 & 0,47 & 21,2 \\
\hline PL & 2,22 & 0,66 & 16,7 \\
\hline $\mathrm{PT}$ & 1,84 & 0,42 & 17,4 \\
\hline $\mathrm{RO}$ & 2,02 & 0,45 & 15,1 \\
\hline $\mathrm{SE}$ & 2,07 & 0,31 & 11,4 \\
\hline $\mathrm{SI}$ & 1,96 & 0,39 & 16,8 \\
\hline $\mathrm{SK}$ & 2,10 & 0,36 & 14,6 \\
\hline $\mathrm{UK}$ & 2,18 & 0,51 & 16,6 \\
\hline EU28 & $\mathbf{2 , 1 2}$ & $\mathbf{0 , 4 4}$ & $\mathbf{1 5 , 4}$ \\
\hline & & & \\
\hline & & & \\
\hline
\end{tabular}

\section{Support cost calculation}

Support costs have been obtained from [10] and are defined as the annual cost of incentives paid to RES-E generation as the result of national support schemes.

\section{Results and discussion}

\section{A. Benefits from $\mathrm{CO}_{2}$ emissions avoided}

Applying the methodology, $\mathrm{CO}_{2}$ emissions avoided in 2013 due to wind energy are $106 \mathrm{MtCO}_{2}$ for the EU-28. Those reductions substantially increase from 2005, when RES-E deployment contributed to reduce $35 \mathrm{MtCO}_{2}$.

A country analysis reveals that almost $63 \%$ of the total reduction is concentrated in three countries (Germany, Spain and United Kingdom). The development of wind energy in these countries is higher than in the rest of Member States.

Those emissions avoided can be translated into monetary terms, by applying a range of the SCC values considered in the review by [20] to the aforementioned emissions reductions. The resulting calculations show that, in monetary terms, the reductions are in the range of $1,482 \mathrm{M} €$, considering the mode $\left(14 € / \mathrm{tCO}_{2}\right)$ and $5,186 \mathrm{M} €$, considering the average value $\left(49 € / \mathrm{tCO}_{2}\right)$, with a central value, provided by calculations made with the median $\left(32 € / \mathrm{tCO}_{2}\right)$ of $3,387 \mathrm{M€}$.

Table III shows the avoided emissions $\left(\mathrm{MtCO}_{2}\right)$ related to wind energy deployment.

\section{B. Benefits from fossil fuel savings}

According to the methodology, $485 \mathrm{TWh}$ of fossil fuel generation have been avoided in 2013 in EU28. The value of those savings per MS depends on its total fossil fuel electricity generation and its electricity mix. Table III shows the primary energy saved by wind energy deployment in the EU MS.

An analysis per country reveals that again, Germany (110 TWh), Spain (108 TWh) and United Kingdom (62 TWh) are the ones experiencing the greatest (absolute) fossil fuel savings as a result of wind energy deployment.

When the aforementioned values are translated into monetary terms, the deployment of wind energy leads to fossil fuel savings of 7,842 M€. Given the high energy dependency of the EU, those savings result in a reduction of fossil fuel imports, with associated benefits in terms of energy independency.

Fossil fuel savings are much higher than savings associated to $\mathrm{CO}_{2}$ emissions reductions in monetary terms, a result in line with [5].

Table III. Avoided $\mathrm{CO}_{2}\left(\mathrm{MtCO}_{2}\right)$ emissions and energy savings (TWh) in 2013

\begin{tabular}{|c|c|c|c|c|c|}
\hline MS & $\begin{array}{l}\text { Avoided } \\
\text { emissions } \\
\left(\mathrm{MtCO}_{2}\right)\end{array}$ & $\begin{array}{c}\text { Fossil fuel } \\
\text { savings } \\
\text { (TWh) }\end{array}$ & MS & $\begin{array}{c}\text { Avoided } \\
\text { emissions } \\
\left(\mathrm{MtCO}_{2}\right)\end{array}$ & $\begin{array}{c}\text { Fossil fuel } \\
\text { savings } \\
\text { (TWh) }\end{array}$ \\
\hline AT & 1.1 & 5.21 & IE & 2.3 & 8.97 \\
\hline $\mathrm{BE}$ & 1.3 & 7.86 & IT & 6.6 & 28.24 \\
\hline BG & 0.7 & 3.01 & LT & 0.2 & 1.14 \\
\hline $\mathrm{CY}$ & 0.14 & 0.53 & LU & 0.0 & 0.13 \\
\hline $\mathrm{CZ}$ & 0.2 & 1.07 & LV & 0.0 & 0.20 \\
\hline $\mathrm{DE}$ & 26.2 & 109.97 & MT & - & - \\
\hline DK & 5.0 & 21.51 & $\mathrm{NL}$ & 2.7 & 11.13 \\
\hline $\mathrm{EE}$ & 0.3 & 1.13 & PL & 3.9 & 13.15 \\
\hline EL & 2.2 & 8.27 & PT & 5.0 & 21.92 \\
\hline ES & 22.2 & 107.89 & RO & 2.0 & 9.15 \\
\hline FI & 0.3 & 1.65 & SE & 3.1 & 20.35 \\
\hline FR & 5.3 & 37.96 & SI & 0.0 & 0.01 \\
\hline HR & 0.2 & 0.87 & SK & 0.0 & 0.01 \\
\hline $\mathrm{HU}$ & 0.3 & 1.45 & UK & 14.4 & 61.93 \\
\hline & & & EU28 & 105.8 & 484.71 \\
\hline
\end{tabular}

C. The costs of public support.

As explained in section 2, virtually all EU MS have implemented some type of RES-E deployment support scheme. Data on the levels of support for wind energy are available for $20 \mathrm{MS}$ in 2013 from [10], with a non-weighted average of 54.2 $€ / M W h$ for the countries being considered. Notwithstanding, support levels widely differ per country, but these differences are not always related to wind energy resource potentials, a result in line with [25].

Table IV provides an analysis of the costs of public support for wind energy and the benefits associated to $\mathrm{CO}_{2}$ emissions reductions and fossil-fuel savings in those countries with available data. Although benefits and costs cannot be directly compared, because the former are distributed amongst citizens while the later are assumed in the majority of MS by electricity consumers, the results show that the aforementioned benefits are relevant for the considered countries as a whole, although they are below the costs.

A country-based analysis reveals that the benefits outweigh the policy costs in ten of the twenty countries with available data. 
Table IV. Summary of the benefits and support costs of renewable energy deployment in EU MS (M€)

\begin{tabular}{|c|c|c|c|}
\hline MS & $\begin{array}{c}\text { Benefits } \mathrm{CO}_{2} \text { emissions } \\
\text { avoided (M€) }\end{array}$ & $\begin{array}{c}\text { Benefits fossil fuel } \\
\text { savings (M€) }\end{array}$ & $\begin{array}{c}\text { Support } \\
\text { Costs (M€) }\end{array}$ \\
\hline AT & 34.3 & 89.8 & 128.1 \\
\hline BE & 42.8 & 120.2 & 334.8 \\
\hline BG & 21.1 & 42.8 & n.a \\
\hline CY & 4.6 & 26.0 & n.a \\
\hline CZ & 7.6 & 15.3 & 35.4 \\
\hline DE & 839.1 & $1,748.0$ & $3,362.0$ \\
\hline DK & 161.4 & 378.7 & 388.9 \\
\hline EE & 10.4 & 20.0 & 4.3 \\
\hline EL & 71.1 & 164.6 & 70.6 \\
\hline ES & 710.7 & $1,712.8$ & $2,398.3$ \\
\hline FI & 9.7 & 23.9 & 32.6 \\
\hline FR & 170.5 & 420.6 & 641.8 \\
\hline HR & 6.0 & 19.2 & 23.5 \\
\hline HU & 8.5 & 24.0 & 48.9 \\
\hline IE & 72.4 & 184.9 & n.a \\
\hline IT & 211.1 & 578.9 & $1,016.7$ \\
\hline LT & 7.9 & 31.0 & 26.9 \\
\hline LU & 0.9 & 3.5 & n.a \\
\hline LV & 1.3 & 4.6 & n.a \\
\hline MT & - & - & n.a \\
\hline NL & 85.5 & 236.4 & 314.3 \\
\hline PL & 124.5 & 219.9 & 430.3 \\
\hline PT & 160.5 & 381.6 & 629.0 \\
\hline RO & 64.4 & 138.0 & 260.8 \\
\hline SE & 99.0 & 231.2 & 227.8 \\
\hline SI & 0.1 & 0.1 & n.a \\
\hline SK & 0.1 & 0.2 & n.a \\
\hline UK & 461.6 & $7,026.1$ & $2,071.5$ \\
\hline EU28 & $3,387.0$ & & $\mathbf{1 2 , 4 4 6 . 5 1}$ \\
\hline & & & \\
\hline
\end{tabular}

Notwithstanding, the results of this research suggest that, even for mature technologies, like wind energy, price-base mechanisms have been an appropriate instrument to encourage the uptake of these technologies which bring substantial social benefits at relatively low support costs. Of course, the picture may be different with significant RES-E penetration levels, whereby problems (and costs) of grid integration may be significantly aggravated and mechanisms without capacity or generation caps may lead to uncontrolled increases in RES-E generation which raise significant concerns in that respect.

\section{Conclusions}

This paper has provided an analysis of the policy costs and some of the most relevant benefits of wind energy deployment in the EU and its MS using an innovative yet internationally validated methodology.

The results show that the support costs for wind energy which are finally paid by electricity consumers in their bills, have led to reductions in $\mathrm{CO}_{2}$ emissions and fossil fuel savings which are below those costs. The fossil fuel savings are higher than the savings associated to $\mathrm{CO}_{2}$ emissions reductions. These results are highly sensitive to the $\mathrm{CO}_{2}$ price In particular, the $\mathrm{CO}_{2}$ price used in the calculations $\left(32 € / \mathrm{tCO}_{2}\right)$ is a central (median) value in the range of the values of social cost of carbon found in the literature, as suggested in [20]. Had the average of those values been chosen $\left(49 € / \mathrm{tCO}_{2}\right)$, the benefits would have clearly offset the policy costs.

These empirical findings bring some policy implications.
First, significant social benefits are induced by each euro of wind energy support paid by electricity consumers.

Second, caution should be taken when proposing the implementation of a more "cost-effective" or "market-based" instrument for the support of RES-E deployment than FITs, as defended by the European Commission [13]. While FITs certainly have problems on their own, the results suggest that, at least in the EU, they have also brought significant social benefits. Despite the criticism, FITs continue to be widely recognised as a benchmark for effective policy design in support of renewable energy expansion. However, the recent legislative move to auctions by the European Commission and some MS may be an appropriate way out, although they may have some problems (as empirically shown by [26]), which might be mitigated with an appropriate choice of design elements. Indeed, if designed properly, auctions can provide as much certainty as FITs regarding remuneration costs while providing an inherent cost-containment mechanism.

Some of the limitations of this work suggest fruitful avenues for further research. First, apart from $\mathrm{CO}_{2}$ emissions avoided and reductions of fossil-fuel dependence, other benefits stemming from Wind energy deployment should be taken into account, including reductions in the emissions of local pollutants, employment effects, impacts on industry creation and innovation and regional and rural development. Second, a full cost-benefit analysis of wind energy deployment is worth carrying out in the future. This could be done by including system costs in the analysis, rather than only support costs as considered in this article. Data availability may represent a formidable challenge in this context, however. Finally the (negative) impact on the conventional fossil-fuel sectors has not been taken into account either. Further investigations which include those factors are recommended.

\section{References}

[1] Del Río, P., Gual, M.A. The promotion of green electricity in Europe. Present and future. European Environment Journal 2004; 14: 219-34.

[2] Breitschopf B., Held A. Guidelines for assessing costs and benefits of RET deployment. Project DIA-CORE (Intelligent Energy Europe) 2014. Contract $\mathrm{N}^{\circ}$ : IEE/12/833/SI2.645735. Available at:

http://diacore.eu/images/files2/D4.1_FhISI_Cost_Benefit_Appr oach_DIACORE.pdf

[3] Garcia-Redondo A.J., Román-Collado R. An economic valuation of renewable electricity promoted by feed-in system in Spain. Renewable Energy 2014; 68: 51-7.

[4] European Commission. Energy Economic Developments in Europe. Directorate-General for Economic and Financial Affairs. Brussels, Belgium (2014). ISBN 978-92-79-35345-1. [5] Marcantonini C, Ellerman A.D. The Implicit Carbon Price of Renewable Energy Incentives in Germany. The Energy Journal 2015; 36 (4): 205-30.

[6] EUROSTAT. Eurostat Statistical Database 2015. Available at:

http://appsso.eurostat.ec.europa.eu/nui/show.do?dataset=nrg_10 5a\&lang=en. Accessed 15 may 2015.

[7] Ragwitz M., Steinhilber S., Breitschopf B., Resch G., Panzer C., Ortner A. et al. RE-Shaping: Shaping an effective and efficient European renewable energy market. Final Report. RE-SHAPING (Intelligent Energy Europe) 2012. Contract $N^{\circ}$ : EIE/08/517/SI2.529243. Available at: http://www.reshapingres-policy.eu/downloads/Final\%20report\%20REShaping_Druck_D23.pdf

[8] Haas R., Panzer C., Resch G., Ragwitz M., Reece G., Held A. A historical review of promotion strategies for electricity from renewable energy sources in EU countries. Renewable and Sustainable Energy Reviews 2011; 15 (2): 1003-34. 
[9] Del Río P. Analysing the interactions between renewable energy promotion and energy efficiency support schemes: The impact of different instruments and design elements. Energy Policy 2012; 38 (9): 4978-89.

[10] CEER. Status Review of Renewable and Energy Efficiency Support Schemes in Europe in 2012 and 2013. Council of European Energy Regulators. Brussels, Belgium (2015).

Available at: www.ceer.eu

[11] Mir-Artigues P., del Río P. Combining tariffs, investment subsidies and soft loans in a renewable electricity deployment policy. Energy Policy 2014; 69: 430-42.

[12] European Commission. RES Legal Europe 2015. Available at: www.res-legal.eu.

[13] European Commission. Communication from the Commission to the European Parliament, the Council, the European Economic and Social Committee and the Committee of the regions. A policy framework for climate and energy in the period from 2020 to 2030. COM/2014/015 final, 2014.

[14] Gutiérrez-Martín F., Da Silva-Álvarez R.A., MontoroPintado P. Effects of wind intermittency on reduction of $\mathrm{CO}_{2}$ emissions: The case of the Spanish power system. Energy 2013; 61: 108-17.

[15] UNFCCC. Tool to calculate the emission factor for an electricity system. Version 04.0. Oct, 2013. United Nations Framework Convention on Climate Change. Bonn, Germany (2013).

[16] Ortega M., del Río P., Montero E.A. Assessing the benefits and costs of renewable electricity. The Spanish case. Renewable and Sustainable Energy Reviews 2013; 27: 294-304.

[17] IPCC. Guidelines for National Greenhouse Gas Inventories. Prepared by the National Greenhouse Gas Inventories

Programme, Eggleston H.S., Buendia L., Miwa K., Ngara T. and Tanabe K. (eds). IGES 2006, Japan.

[18] European Commission. Commission Decision 2004/156/EC of 29 January 2004 establishing guidelines for the monitoring and reporting of greenhouse gas emissions pursuant to Directive 2003/87/EC of the European Parliament and of the Council (notified under document number C(2004) 130).
[19] Price R., Thornton S., Nelson S. The Social Cost of Carbon and the Shadow Price of Carbon. What they are and how to use them in economic appraisal in the U.K. Department for Environment, Food and Rural Affairs. London, United Kingdom (2007). Available at:

https://www.gov.uk/government/uploads/system/uploads/attach ment_data/file/243825/background.pdf

[20] Tol R.S.C. A cost-benefit analysis of the EU 20/20/2020 package. Energy Policy 2012; 49: 288-295.

[21] European Commission. Commission Implementing Decision 2011/877/EU of 19 December 2011 establishing harmonised efficiency reference values for separate production of electricity and heat in application of Directive 2004/8/EC of the European Parliament and of the Council and repealing Commission Decision 2007/74/EC (notified under document C(2011) 9523).

[22] BP. BP Statistical Review of World Energy 2013. Available: http://www.bp.com/content/dam/bp/pdf/statisticalreview/statistical_review_of_world_energy_2013.pdf. Accessed February 8, 2015.

[23] IMF. International Monetary Fund 2015. Available at: http://www.imf.org/external/np/res/commod/index.aspx. Accessed October 8, 2015.

[24] MINETUR. Annual Electricity Statistics. Ministry of Industry, Energy and Tourism of Spain. Madrid, Spain (2014). Available at:

http://www.minetur.gob.es/energia/balances/Publicaciones/Elec tricasAnuales/Paginas/ElectricasAnuales.aspx. Accessed January 23, 2015.

[25] del Río P., Tarancón M.A., Peñasco C. The determinants of support levels for wind energy in the European Union. An econometric study. Mitigation and Adaptation Strategies for Global Change 2014; 19(4): 391-410.

[26] Del Río P., Linares P. Back to the future? Rethinking auctions for renewable electricity support. Renewable and Sustainable Energy Reviews 2014; 35: 42-56. 